ROZALYA SASOR

UNIWERSYTET JAGIELLOŃSKI

InSTYTUT FILOLOGII ROMAŃSKIEJ

ZAKŁAD IBERYSTYKI

RSASOR@GMAIL.COM

\title{
PROCES KSZTAŁTOWANIA SIĘ KATALOŃSKIEJ ŚWIADOMOŚCI NARODOWEJ NA PRZYKŁADZIE LEGENDY O OTGERZE CATALÓ
}

\section{Katalońska tożsamość narodowa jako problem polityczny}

Analiza, czy to socjologiczna, czy historyczna, czy wreszcie kulturowa hiszpańsko-katalońskiego sporu o tożsamość to zagadnienie tak obszerne, że wykracza nie tylko poza objętość jednego artykułu, ale również poza możliwości badawcze jednego specjalisty. Tym niemniej, zważywszy na nikłą obecność tematów katalońskich w nauce polskiej, warto przedstawić choćby przyczynek do problemu, z nadzieją, że wzbudzi on szersze zainteresowanie i zachęci do zgłębiania materii przedmiotu. Mając świadomość wszystkich wymienionych wyżej ograniczeń, chciałabym nakreślić kwestię wpływu dyskursu politycznego na proces kształtowania się katalońskiej świadomości wspólnotowej, którego jednym ze świadectw jest późnośredniowieczna legenda o Otgerze Cataló, założycielu Katalonii. Fundamentem dla tych rozważań, a także narzędziem pozwalającym zrozumieć rozgrywający się w Hiszpanii od kilku już lat konflikt wokół pojęcia narodowości w odniesieniu do Katalonii i Katalończyków, są dwa podstawowe założenia teoretyczne, które pozwolą uniknąć subiektywności spojrzenia jednej lub drugiej, zaangażowanej w spór strony. Po pierwsze, tożsamość etniczna, kulturowa, czy wreszcie narodowa jest tworem plastycznym i jako taki podlega nieustannym zmianom w procesie historycznym. Po drugie, na jej kształt wpływa 
dyskurs polityczny ośrodka władzy, który dąży do takiego przeformułowania tożsamości, by ta mogła stanowić dla niego legitymizację.

Ewolucja katalońskiej świadomości etnicznej również przechodziła przez kolejne stadia i można ją podzielić na trzy, następujące po sobie etapy. Pierwszy to samoprzypisanie do wspólnoty politycznej Franków funkcjonujące od czasów powołania Marchii Hiszpańskiej do XII w. Drugi stanowi wykształcenie się odrębności względem sąsiadów i pojawienie się endoetnonimu - Katalończycy (XII w.), natomiast trzecie stadium to uformowanie silnego poczucia wspólnoty narodowej (XIII w.), które rozszerzając się z czasem, objęło przynależność do narodu hiszpańskiego (od XVIII w.).

Współcześnie, ostatni etap ewolucji katalońskiej tożsamości, to jest samookreślanie się ponad połowy Katalończyków jako osób o podwójnej narodowości, uczestniczących w dwóch, blisko spokrewnionych kulturowo systemach ${ }^{1}$, kwestionowany jest przez te środowiska, które w aspirującej katalońskiej samoświadomości etnicznej widzą zagrożenie dla jedności państwa hiszpańskiego. Do niedawna kontestacja taka nie miała racjonalnych podstaw, ponieważ Katalończycy w całej swojej historii unii z Hiszpanią tylko raz, podczas rebelii w 1640 r., proklamowali niepodległość ${ }^{2}$, i dopiero wydarzenia ostatnich dziesięciu lat, wyraźnie pokazujące wzrost tendencji separatystycznych w katalońskim społeczeństwie, mogą budzić ten rodzaj niepokoju.

Można się jednak zastanowić, czy wola samookreślenia się jako narodu lub dążenie do utworzenia suwerennej Republiki Katalońskiej kosztem hiszpańskiej integralności terytorialnej mogą lub powinny wpływać na ocenę charakteru katalońskiej tożsamości? Czy przyznanie Katalończykom prawa do posługiwania się określeniem nacionalitat (hiszp. nacionalidad, 'narodowość'), ale już nie nació (hiszp. nación, 'naród'), ma inne uzasadnienie niż po-

1 Według sondażu BOP (Baròmetre d’Opinió Política - Barometr Opinii Politycznych) 2015 r. poczucie przynależności narodowej wśród Katalończyków kształtuje się w następujący sposób: 5,6\% badanych czuje się Hiszpanami; 4,5\% - bardziej Hiszpanami niż Katalończykami; 38,7\% zarówno Hiszpanami, jak i Katalończykami; 22,3\% - bardziej Katalończykami niż Hiszpanami i 25,3\% - tylko Katalończykami (BOP, 2015: 56).

2 Republika proklamowana w 1931 r. przez Francesca Macià i w 1934 przez Lluísa Companysa miała być krajem federacyjnym w obrębie państwa hiszpańskiego. Władze niepodległej Republiki ogłoszonej przez Paua Clarisa w 1640 bardzo szybko zrezygnowały z pełnej suwerenności i ogłosiły Ludwika XIII hrabią Barcelony, włączając tym samym Katalonię w struktury państwowe Francji. 
trzeby ekonomiczne i polityczne władzy?3 Przecież opozycja jednej grupy $\mathrm{w}$ stosunku do innej, powstała w procesie formowania się świadomości społecznej, nie musi być równoznaczna $\mathrm{z}$ nastawieniem separatystycznym. Pozwala, owszem, na zbudowanie poczucia odrębności, które z kolei prowadzi do samookreślenia danej grupy, ale ma przede wszystkim charakter spajający dla wspólnoty. W przypadku Katalonii owa „jednocząca opozycja” kształtowała się, w różnych okresach historycznych, w konfrontacji z odmiennymi kulturowo społecznościami al-Andalus, Kastylii i Francji. Oczywiście, dużo trudniejszy do sprecyzowania jest zakres odrębności narodowej, ponieważ nie zawsze opiera się ona na cechach jednoznacznie identyfikujących jak język, religia czy ciągłość kulturowa i/lub historyczna, ale również na elementach wolicjonalnych, których dystynktywny charakter można łatwo podważyć, a mimo tego są one uznawany przez daną grupę za wyróżnik tożsamości. Na gruncie katalońskim odrębność językowa wykształciła się stosunkowo wcześnie, bo już XIII w. język kataloński był w pełni samodzielnym i sprawnym narzędziem nie tylko literatury, ale również nauki. Identyfikacja religijna zbudowana została na fundamencie konfliktu chrześcijańsko -muzułmańskiego i walk prowadzonych w procesie rekonkwisty. Natomiast ciągłość kulturową i historyczną zapewniała wspólnocie początkowo dynastia hrabiów Barcelony, a od XV w. baza terytorialna. Elementem wolicjonalnym jest zaś tradycja katalońskiej państwowości, szeroko dziś komentowana, ponieważ od czasów połączenia hrabstwa Barcelony z Królestwem Aragonii, Katalonia nie funkcjonowała jako samodzielny organizm państwowy, a jedynie jako część federacji.

Jednocześnie to wzajemne wpływy kulturowe różnych grup etnicznych i narodowych oraz wspólność komponentów językowych i historycznych rozszerzają, lub nawet zmieniają, zakres tego, co dana wspólnota uznaje za swoiste i reprezentatywne. Dla przykładu, XIX w., będący okresem tzw. katalońskiego odrodzenia narodowego, to jednocześnie czas niemal całkowitej dominacji języka hiszpańskiego, tak w kulturze, jak i nauce, czy polityce. To właśnie wtedy powstają opracowania historyczne i powieści spisane w znakomitej większości po kastylijsku - o charakterze rewindykacyjnym i jednoznacznym, czytelnym przesłaniu patriotycznym, w których

3 Na temat różnic pomiędzy pojęciami nacionalidad (narodowość) i nación (naród) w ujęciu prawnym w hiszpańskiej Konstytucji por. M. Biernacka [2015], Współczesne tendencje separatystyczne w Kraju Basków. Pragmatyka społeczna oraz Konstytucja Hiszpanii jako legislacyjna blokada secesji, zwłaszcza sekcja „Nación versus nacionalidades, czyli o różnicy między narodem a narodowościami w konstytucji Hiszpanii jako blokadzie legislacyjnej separatyzmu": 161-162. 
autorzy domagają się uznania odrębności narodowej ${ }^{4}$. Wydaje się zatem, że hiszpański problem z katalońską tożsamością mniej dotyczy samego jej charakteru - z definicji poddającego się ewolucji - co ambicji politycznych jednej i drugiej strony. Stąd też drugie założenie teoretyczne moich rozważań.

\section{Katalońska tożsamość narodowa jako problem historyczny}

Mianowicie tożsamość określonej grupy społecznej jest formowana i przeformułowywana zgodnie $\mathrm{z}$ dyskursem jej politycznego ośrodka władzy, który szuka dla siebie legitymizacji we wspólnej pamięci i ciągłości przywództwa w czasie historycznym. W przypadku Katalonii ten aspekt tworzenia się, a następnie przekształcania samoświadomości grupowej najłatwiej zaobserwować na przykładzie wczesnośredniowiecznych kronik łacińskich, spisywanych przez duchownych związanych z dynastią hrabiów Barcelony. Dla pierwszych kronikarzy, takich jak biskup Gotmar II z Girony (X w.), tożsamość polityczna regionu nie budziła najmniejszych wątpliwości, ponieważ upatrywali jej korzeni w „państwotwórczej” działalności władców frankijskich, Karola I Wielkiego i jego syna, Ludwika Pobożnego, prowadzących wojny z muzułmańskimi królestwami na Półwyspie Iberyjskim. Na terenach należących obecnie do Katalonii, wzdłuż masywu Pirenejów, istniała od czasów Karola Wielkiego strefa buforowa, zwana marca Hispànica, oddzielająca królestwa frankijskie od muzułmańskich. Jej mieszkańcy, o trudnej dziś do określenia przynależności narodowej, zwali sami siebie Frankami, jako że zamieszkiwane przez nich terytorium było zależne pod względem politycznym i religijnym od Akwitanii i Septymami [Sholod, 1966: 62 $]^{5}$. Stąd też tytuł, jaki wspominany wcześniej biskup Gotmar nadał swojej kronice - Llibre dels reis francs - którą obdarował kordobańskiego księcia al-Hakama, w 940 r., jako ambasador Sunyera, hrabiego Barcelony [Balcells, 2004: 21]. Z perspektywy dalekiej Andaluzji określenie „królowie

4 Kwestię narodowych aspiracji autorów tak hiszpańsko, jak i katalońskojęzycznych wieku XIX omawia szeroko Magí Sunyer w swojej publikacji poświęconej katalońskiej mitologii narodowej [Sunyer, 2014].

5 Na temat istnienia lub nie Marchii Hiszpańskiej jako samodzielnego administracyjnie terytorium w granicach królestwa Karola Wielkiego oraz jej ewolucji pisze Félix Martínez Llorente w artykule Cataluña en sus orígenes. La Marca Hispánica, una frontera entre dos mundos, gdzie zwraca uwagę na sztuczność powszechnie wykorzystywanego we współczesnej historiografii terminu. Jednocześnie podkreśla dającą się zaobserwować już na początku IX w. pewną odrębność polityczną hrabstw Marchii, wśród których dominującą rolę zyskało hrabstwo Barcelony jako przyszły ośrodek władzy Katalonii [Martínez Llorente, 2014]. 
frankijscy" miało całkowicie naturalny charakter, ponieważ hrabstwa skupione w granicach tzw. Marchii Hiszpańskiej widzieli jako jeden organizm państwowy, zwany Ifranja [Barceló Perello, 1979: 131]. Podobnie, jeszcze w XII w., Frankami nazywali Katalończyków mieszkańcy Kastylii, czego echo znajdziemy w najważniejszym eposie języka kastylijskiego, Pieśń o Cydzie (Poema de mio Cid), gdzie w eopizodzie poświęconym straciu między Cydem a hrabią Barcelony Ramonem (strofy 58 i nn.), wojska katalońskie określane są wspólnym mianem francos ([PmC, 2006].

Jednocześnie, na bazie systemu feudalnego, stopniowo wzmacniała się dominiacja hrabstwa Barcelony pomiędzy innymi hrabstwami Marchii, aż do pełnego skonsolidowania władzy i utworzenia suwerennego regionu, którego władca - Ramón Berenguer IV - przejął w 1137r. tron Królestwa Aragonii, żeniąc się z aragońską dziedziczką, księżniczką Peronellą. Pomnikiem historiografii tego okresu jest kolejna kronika, tym razem łacińsko-katalońska, znana jako Gesta comitum Barcinonensium, spisana w klasztorze Ripoll najprawdopodobniej na zlecenie Alfonsa II Aragońskiego, pomiędzy okresem 1180-84 (GCB I, część najdawniejsza) a początkiem XIV w. (GCB III), [Barrau-Dihigo i Massó Torrents, 2007: 27]. Kronika podaje genealogię hrabiów Barcelony oraz królów Aragonii z dynastii barcelońskiej, a ponadto jest świadectwem ewolucji myśli politycznej, ukazując zmiany zachodzące w koncepcji władzy i państwa, a w konsekwencji - świadomości wspólnoty katalońskiej [Cingolani, 2011: 8]. Jak pisze Cingolani, część zawierająca listę władców wymienia na pierwszym miejscu mityczną postać hrabiego Wilfreda d’Arrià, ojca Wilfreda I Kudłatego łączonego z póżniejszą o ponad trzy wieki legendą o powstaniu katalońskiej flagi. Przy czym kronika nie opowiada dziejów wspólnoty narodowej, lecz koncentruje się na historii jednego rodu, a jej genealogiczny charakter ma wskazać moment, w którym rozpoczyna się proces przekazywania władzy feudalnej, uzyskanej z rąk frankońskiego władcy, w obrębie jednej linii dynastycznej, czyli tym samym potwierdzać prawo rodowe do zajmowanych terytoriów. Jednocześnie legenda o zabójstwie Wilfreda d'Arrià, odmowie udzielenia pomocy militarnej Wilfredowi Kudłatemu przez króla Franków i zerwaniu, w konsekwencji, więzów wasalnych z Karolingami miała na celu uwypuklenie suwerenności regionu i pełnej niezależności politycznej oraz administracyjnej hrabiów Barcelony, gdzie sam akt obrony ziemi przed najazdem Saracenów legitymizował do niej prawo obrońców. W tym momencie najważniejszym problemem przyszłej Katalonii było umocnienie dynastii hrabiowskiej, która sięgnęła po tytuł królewski i w której 
interesie było ugruntowanie władzy przez konsolidację terytorium i wyodrębnienie go jako samodzielnego bytu. Cel ten zamierzano osiągnąć rezygnując z uczestnictwa we wspólnocie etnicznej Franków, a następnie budując nową, niezależną wspólnotę katalońską.

Polityczna potrzeba uzasadnienia ciągłości rozszerzającej się stopniowo władzy hrabiów Barcelony doprowadziła do wyodrębnienia i nazwania zarządzanego regionu Katalonią, a jej mieszkańców - Katalończykami, tj. do przeformułowania tożsamości etnicznej. Pierwszy, udokumentowany zapis toponimu ${ }^{6}$ znajduje się w łacińskim Epitafium powstałym niedługo po śmierci hrabiego Ramona Berenguera IV (1162): „Vox in Cathalonia et in Aragonia sonet" [Flórez de Setién i Risco, 1819: 466], tam też pojawia się etnonim: „plebs Cathalana et Aragonensis” oraz „Patres et Domini Cathalani et Aragonenses" [Flórez de Setién i Risco, 1819: 468-9], określenia, które od drugiej połowy XII w. weszły do powszechnego użytku. Chociaż sama etymologia onimów Catalunya i català nie jest znana do dzisiaj ${ }^{7}$, to wyjaśnienie konieczności ich pojawienia się nie nastręcza większych problemów, o ile zwrócimy uwagę na sytuację polityczną regionu. W $1137 \mathrm{r}$. hrabia Ramon Berenguer IV przejmuje prawa do korony aragońskiej oraz tytuł króla, awansując tym samym w hierarchii feudalnej. Od tego momentu dynasta hrabiów Barcelony włada nie tylko konglomeratem hrabstw tworzących przyszłą Katalonię, ale również terenami należącymi do Królestwa Aragonii, które kolejni władcy będą powiększać o Walencję, Baleary, Sycylię czy Neapol. Duma z własnego dziedzictwa oraz przekonanie o dominującej roli hrabstwa w aragońskiej konfederacji obligowały do podniesienia prestiżu wspólnoty, która z grupy władanej, szukającej tożsamości we wspólnocie etnicznej Franków, przekształciła się w grupę sprawującą władzę. Taka nobilitacja wymagała ugruntowania historycznej odrębności nie tylko na lokalnym, ograniczonym poziomie jednego rodu, ale przede wszystkim na szerszej płaszczyźnie etnicznej, stąd wprowadzenie wyżej wspomnianych

6 Zapis ten powstał w interesującym mnie obszarze geograficznym przyszłej Katalonii, pierwsze udokumentowane użycie etnonimu i toponimu znajduje się w spisanej po łacinie, włoskiej kronice Liber Majolichinus (ok.1114), będącej relacją ze wspólnej wyprawy hrabiego Barcelony i pizańczyków przeciw mauryjskim piratom z Balearów [Coromines, 1995: 335].

7 Coromines wymienia kilka hipotetycznych etymologii: od Gotholandia, czyli „ziemia Gotów”; od castellani, tj. „ludzie z zamku”; od catalauni, domniemanej nazwy celtyckiego plemienia zamieszkującego tereny Pól Katalaunijskich; od Montecatanus, łacińskiej nazwy miejscowości Montcada, położonej niedaleko Barcelony, i wszystkie je odrzuca jako pozbawione wiarygodności historycznej i lingwistycznej. Sam jednocześnie proponuje nową etymologię, od nazwy rdzennego, katalańskiego plemienia - Lacetani [Coromines, 1995: 335-9]. 
onimów i, w konsekwencji, budowanie zaplecza legendarno-historycznego, które miało stać się fundamentem dla świadomości narodowej.

\section{Tożsamość historyczna i fikcja}

Kształtowanie się katalońskiej tożsamości nie jest zatem procesem sztucznie wykreowanym w czasach nam współczesnych, czy to na substracie niezadowolenia ekonomicznego, jak chcą niektórzy, czy też w efekcie rozbuchania roszczeń nacjonalistycznych. Jak pokazuje materiał historyczny, katalońska wspólnota narodowa, w andersonowskim rozumieniu tego pojęcia, wytworzyła się bardzo wcześnie, bo już w okresie średniowiecza, na co dostarczają dowodów wspomniane wyżej kroniki łacińskie. Natomiast jej rozwój połączony z pogłębianiem się świadomości wspólnotowej opisują tzw. cztery najważniejsze kroniki katalońskie (Les quatre grans cròniques catalanes), spisane, kolejno, przez króla Jakuba I Zdobywcę (poł. XIII w.), kronikarza Bernata Desclota (1288), żołnierza Ramona Muntanera (1325-58) oraz króla Piotra III Ceremonialnego (1382-25). Żadna z nich wprawdzie nie koncentruje się na konkretnych mitach fundacyjnych, jednak wszystkie podkreślają odrębność Katalończyków jako wspólnoty skupionej wokół postaci władcy z dynastii hrabiów Barcelony.

Pierwszym sensu stricto mitem założycielskim jest opowieść o Otgerze Cataló. Jest to legenda stosunkowo późna, bo jej pierwsza wersja powstała dopiero w 1418 r., ale dlatego też ciekawa dla badacza, ponieważ może on śledzić jej rozwój z bliska, opierając się na bogatym materiale źródłowym i badać relacje łączące mit z rzeczywistością społeczną i historyczną. A związki te są wyjątkowo silne. Podobnie jak w XII w., kiedy potrzeba polityczna wymusiła stworzenie „nowej formuły narodowej”, w XV w. pojawiła się potrzeba obrony ukształtowanej już tożsamości i skonfrontowania jej nie tylko z polityką, ale również z narodową tradycją nowych władców na aragońskim tronie: kastylijskich królów z dynastii Trastámara. W 1410 r. zmarł bezpotomnie ostatni król-hrabia, Marcin I Ludzki, a o schedę po nim starali się dwaj kandydaci: Jakub II, hrabia Urgell oraz Ferdynand de Antequera, młodszy syn króla Kastylii, Jana I, Jakub II, jeszcze za życia Marcina Ludzkiego, otrzymał tytuł namiestnika królestwa (governador general), który, po śmierci władcy, interpretowano w Katalonii jako tytuł do korony. Tymczasem Aragonia opowiedziała się za Ferdynandem, siostrzeńcem zmarłego króla, kiedy ten, odwołując się do królewskiego testamentu, przedstawił swoje prawa do tronu jako prawowity potomek dynastii rządzącej. Aragonię wsparła Walencja, 
antypapież Benedykt XIII oraz, rzecz jasna, Kastylijczycy, gdy tymczasem popierany przez Katalończyków hrabia Urgell gromadził wojska - obie strony szykowały się do wojny domowej. Sytuacja taka trwała do 1412 r., gdy na mocy tzw. Kompromisu z Casp, dziewięciu reprezentantów trzech regionów tworzących królestwo, tj. Aragonii, Walencji i Katalonii przyznało Ferdynandowi prawo do tronu i uznało jego wybór za prawomocny. Chociaż sama decyzja zapadła dużo wcześniej niż dziewięciu w ogóle się zebrało i nie było to dla nikogo tajemnicą [Soldevila, 1962: 572 i nn.].

Nowy władca $z$ niechęcią odnosił się do nieprzyjaznych mu poddanych w Katalonii, ci zaś nie pozostawali mu dłużni, oskarżając Ferdynanda, a potem jego następców, o nieprzestrzeganie umów uprawniających wszystkie stany do udziału w rządach (system zwany po katalońsku pactisme) oraz doprowadzenie barcelońskiej potęgi morskiej do ruiny [Valls i Taberner i Soldevila, 2002: 266]. Poczucie zagrożenia katalońskiej arystokracji wyrażało się, m.in., w zapotrzebowaniu na legendy fundacyjne, które miały wykazać jej polityczną siłę i prawo do współrządzenia królestwem. I tak pojawił się Otger Cataló.

Pierwsza wersja mitu pochodzi, jak wspominałam, z 1418 r. i zachowała się $\mathrm{w}$ rękopisie przechowywanym w Bibliotece Uniwersyteckiej w Walencji (ms. 92-6-12) w następującej postaci:

W roku pańskim 732 wiedzcie, że w prowincji Gaskonii znajdował się zamek, który zwał się Cathaló. I zamek ów należał do pewnego rycerza, wielce szlachetnego i mężnego w boju, i postanowił on zdobyć Barchinonę, bowiem była w mocy ludzi niewierzących w Boga. Ów rycerz, z wielką gromadą ludzi z onego zamku oraz okolic, przybył oblegać i bić się o rzeczone miasto Barchinona, które należało do Gotów, i miały tam miejsce ciężkie walki, w których zginęło wielu ludzi po każdej stronie. Aż Goci, którzy mieli w mocy rzeczone miasto, gdy ujrzeli, że nie mogą poradzić sobie z tymi z zewnątrz [oblegającymi], uradzili, że poddadzą się owemu rycerzowi i tak też uczynili. I zaraz ów rycerz ze swoimi ludźmi wszedł do miasta Barchinona, a że ludzi miał wielką gromadę, ci, którzy nie pomieścili się w rzeczonym mieście, musieli pomieścić się w okolicy Barchinony. Oni zaś, rycerze i piesi, wzięli tam sobie żony spomiędzy wdów i panien, ich córek, pochodzenia gockiego, ponieważ były to niewiasty bardzo piękne i dobrze wykształcone, i mieli z nich synów i córki, i nauczyli ich języka ojców. I z czasem mnożyli się i rozrastali, i zapomnieli wspólny język i stworzyli nowy, ze słów, które wzięli od swych ojców i innych, które wzięli od matek, którzy to ojcowie byli Gaskończykami, a matki Gotkami. I w ten sposób, od tego czasu, mieszkańcy inszych ziem nazywali owych ludzi z Barchinony cathalans [Katalończykami], ponieważ 
ich ojcowie i ich przyjaciele, i ich przodkowie pochodzili z rzeczonego zamku, co zwał się Cathaló. I od owej nazwy Cathaló nazwano jego mieszkańców cathalans, i potem nie stracili oni owej nazwy [Coll i Alentorn, 1947-8: 13] ${ }^{8}$.

Wczesna wersja legendy ma jeszcze charakter etymologiczny, wskazując na pochodzenie toponimu Katalonia i etnonimu Katalończycy od nazwy gaskońskiego zamku Cathaló. Co ciekawe, autor opowieści przesuwa okres formowania się katalońskiej tożsamości etnicznej do czasów sprzed wypraw Karola Wielkiego, tj. do 732 r., nawiązując, z jednej strony, do XII -wiecznej tradycji zrywającej z frankońskim pochodzeniem, a z drugiej, do panującej w całej Hiszpanii w XV wieku mody na korzenie gockie, które miały mieć szczególnie nobilitujący charakter [Caja López, 2011: 14]. Dla rodzimej, katalońskiej arystokracji legenda miała również znaczenie polityczne, ponieważ potwierdzała historyczność katalońskiej wspólnoty, jej suwerenność i niezależność od innych formacji państwowych, a tym samym świadczyła na rzecz legitymizacji praw Katalończyków do udziałów w rządach kastylijskiego króla.

Kolejna wersja legendy, z 1431 r., idzie jeszcze dalej, ponieważ prócz tego, że bohater otrzymuje w niej imię Otger, stając się postacią bardziej namacalną i autentyczną, to wymienia dziewięć przydomków rodowych szlacheckich rodzin katalońskich, nadając im tym samym szczególny status. Tekst legendy pochodzi z rękopisu przechowywanego w Bibliotece Narodowej w Paryżu (ms. esp.13) i brzmi, jak następuje:

W czasach, kiedy Maurowie władali pryncypatem Katalonii, lub większą jego częścią, i większą częścią Hiszpanii, wkroczył na owe ziemie wielki dowódca pochodzący z Francji, który zwał się Otger Cathaló. A przybyło z nim w drużynie dziewięciu baronów, którzy podzielili się na trzy drużyny po trzech, a są to, jak następuje: Muntcades, Pinós i Mataplanes; Cerveres, Servellons i Alamanys; Anglasoles, Ribelles i Arills. A z nimi przybyło wielu rycerzy i szlachciców, by zdobyć ową ziemię dla chrześcijańskiej wiary. I w trakcie walk zmarł z choroby rzeczony dowódca, zwany Otger Cathaló, w czasie oblężenia Empúries, i od jego imienia nadali owej ziemi jej nazwę, to jest Cathalunya [Katalonia]. A z przyczyny wielkiej gromady Maurów, chrześcijanie wycofali się w góry, do kamiennych zamków, i tak się bronili przed Maurami, aż cesarz Karol Wielki nie przybył i nie podbił całej Hiszpanii, a zwłaszcza pryncypatu Katalonii, gdzie naszedł owych dziewięciu baronów. I podzilił

8 Wszystkie cytowane w niniejszym artykule fragmenty tekstów podaję w przekładzie własnym z języka katalońskiego. 
rzeczony pryncypat na dziewięć części na cześć dziewięciu chórów anielskich w następujący sposób: dziewięć hrabstw, dziewięć wicehrabstw, dziewięć rodów możnowładczych, dziewięć varvessors ${ }^{9}$ i dziewięć setek rodów szlacheckich. W każdym hrabstwie było jedn wicehrabstwo, jeden możnowładca i jeden varvessor. [Tu następuje lista przedstawiająca szczegółowy podział administracyjny Katalonii, z której warto wymienić utworzone przez Karola Wielkiego hrabstwa: Rosselló, Empúries, Barcelona (Barchinona), Tarragona, Urgell, Pallars, Cerdanya, Osona i Besalú - dop. R. S.]

I dziewięć setek rodów rycerskich i szlacheckich.

Było tak, aż nastał hrabia Barcelony zwany Borell, który zobaczył, że na jego ziemiach jest coraz mniej ludzi szlachetnie urodzonych, ponieważ w walkach ginęli każdego dnia. Dlatego powołał on kolejne dziewięć setek rodów i dał im przywileje wojskowe, a z poddanych, którymi byli, uczynił ich ludźmi wolnymi [Coll i Alentorn, 1947-8: 14-5].

Chociaż czas powstania obydwu wersji legendy nie jest aż tak odległy, wersja nowsza wyraźnie czerpie z innych źródeł: przesuwa datę wkroczenia francuskiego rycerza do Katalonii do czasów Karola Wielkiego, wprowadza jego imię - Otger, zmienia wroga - z Gotów na Maurów, podaje odmienną etymologię toponimu oraz, co najważniejsze, dołącza nowych bohaterów, tj. dziewięciu baronów, i opisuje podział regionu na dziewięć hrabstw. Wspólnych elementów jest dużo mniej: w obydwu wersjach dowódca o przydomku Cataló przybywa zza Pirenejów i walczy z przeciwnikiem odmiennego wyznania, aby odzyskać Katalonię „dla chrześcijańskiej wiary”. Francuskie pochodzenia Otgera jest niewątpliwie reminiscencją okresu, w którym dominowało przekonanie o frankońskiej tożsamości etnicznej przyszłych Katalończyków, przy czym każda z wersji rozwiązują ten motyw na swój sposób. Pierwsza odżegnuje się od jakiejkolwiek zależności od francuskich królów, natomiast druga ją podkreśla, wprowadzając postać Karola Wielkiego, któremu przysługuje prawo reorganizacji administracyjnej regionu, co jest równoznaczne z posiadaniem nad nim pełnej władzy. W pierwszej połowie XV w., krótko po intronizacji Ferdynanda de Antequera, pojawiła się potrzeba zaznaczenia nie tylko odrębności, ale przede wszystkim prawa do władzy katalońskiej arystokracji rywalizującej ze szlachtą aragońską i kastylijską, potrzeba, którą zrealizowano przez przypomnienie dawnego mitu uzupełnionego o aspekt genealogiczny, a także elementy wzmacniające jego znaczenie, takie jak: walka o ziemię, czy to z Gotami czy Sara-

9 Stopień dawnej hierarchii feudalnej, chociaż uważa się, że varvessor nie był rzeczywistym tytułem, a oznaczał po prostu wasala [Aguiló, 1934: 218]. 
cenami, oraz przyłączenie jej do chrześcijańskiej wspólnoty, czyli, pośrednio, uzyskanie boskiej aprobaty dla podboju i ustanowienia nowej władzy. W momencie politycznej destabilizacji państwa uwypuklenie dawności praw jednej z współtworzących je wspólnot stanowiło dla niej warunek sine qua non dalszego istnienia.

Analiza materiału historycznego odsłania proces adaptacji źródeł pisanych na potrzeby osiągnięcia satysfakcjonującego polityczne ambicje katalońskiej arystokracji rozwiązania i prowadzi do tekstu, na którym najprawdopodobniej bazował twórca drugiej wersji katalońskiej legendy fundacyjnej, tj. do apokryficznej kroniki łacińskiej Gesta Karoli Magni ad Carcassonam et Narbonam przypisywanej niejakiemu Philomenie, który miał być sekretarzem Karola Wielkiego. Kronika, znana w Katalonii przynajmniej od połowy XIV w., rozpowszechniana była także w przekładzie na język oksytański, blisko spokrewniony z katalońskim. Gesta opowiada o czynach Karola Wielkiego i obejmuje także opis walk z Saracenami w Katalonii, prowadzonych przez Rolanda, Ogiera Duńczyka i księcia Normandii, którzy „po drugiej stronie gór” zdobywali dla swojego króla bogate łupy w zwierzętach (byki, krowy, konie, muły), ludziach (ponad 2700 niemowląt natychmiast ochrzczonych z rozkazu Karola) i dobrach materialnych (złoto, jedwabie, złotogłowy). Podczas jednego z rajdów rycerze owi zajęli całą Cerdanyę, część regionu Girony, Lleridę, Balaguer i dopiero w drodze na Barcelonę zwycięską drużynę zatrzymały połączone wojska dwudziestu saraceńskich władców. Ustępując pod naporem Saracenów, Karolowi rycerze schronili się w górach, w Urgell, gdzie wywiązała się bitwa z trzema królami, w czasie której chrześcijanie zabili, prócz samych królów, 134 tys. Saracenów, tracąc zaledwie czterystu ludzi, spośród których kronika wymienia imię tylko jednego - Ogiera z Normandii (Augerius de Normandia, w wersji łacińskiej i Augier de Normandia w prowansalskiej). W powiązaniu ze śmiercią Ogiera pojawia się w Gesta znana z katalońskiej legendy miejscowość Empúries, gdzie Roland zatrzymał się po bitwie i skąd został wyparty przez Marciliusa, saraceńskiego władcę, który zajął cały region Empúries i Rosselló. Opowieść kończy wezwanie o pomoc przesłane do Karola przez Rolanda [Philomena, 1898: 30-3, 46-9, 88-9].

Zbieżność apokryficznej historii z udziałem Ogiera z Normandii z fundacyjnym mitem o Ogierze Cataló nie może być przypadkowa. Poza tym imię Otger, będące katalońską wersją polskiego Ogiera, nie było w Katalonii nieznane. Postać Ogiera Duńczyka, jednego z najważniejszych bohaterów epickiego cyklu karolińskiego, pojawia się w Pieśni o Rolandzie 
oraz rozpowszechnionych w Katalonii pieśniach poświęconych tylko temu bohaterowi. Najwcześniejszy ślad przyswojenia przez kulturę katalońską postaci Ogiera Duńczyka znajdziemy w dydaktyczno-satyrycznym poemacie Ensenhament (Nauka o sztuce żonglerskiej) spisanym ok. 1170 r. po oksytańsku przez wicehrabiego Girony i Cabrery, Gueraua III de Cabrera, katalońskiego szlachcica i trubadura. Poemat zadedykowany żonglerowi Gueraua, noszącemu przydomek Cabra, oddaje panoramę literacką epoki, koncentrując się na radach dla żonglerów dotyczących sposobu wykonywania pieśni oraz ich tematów, wśród których pojawia się aż dwukrotnie imię duńskiego rycerza: duc Augier oraz Danes [Riquer, 1980: 66]. Augiers gości również w satyrycznej piosence kolejnego katalońskiego trubadura, Guillema de Berguedà, o incipicie Mal o fe lo bisbe d'Urgel, gdzie autor w niewyszukanych słowach wyraża swoją niechęć do biskupa, który obłożył go ekskomuniką ${ }^{10}$. W XIII w. Duńczyk pojawia się na kartach Kroniki Bernata Desclota, a inwentarze biblioteczne z kolejnego stulecia, jak na przykład inwentarz księgozbioru Marcina Ludzkiego (†1410) albo księcia de Viana ( $\dagger 1461)$, w których znaleziono teksty zatytułowane wsprost Ogier de Danois, wskazują na wielką poczytność francuskiej literatury wśród katalońskiej arystokracji. Wreszcie ostatnim źródłem popularności Duńczyka może być Kronika Pseudo-Turpina znana w Katalonii od 1173 r. [Coll i Alentorn, 1947-8: 20]. Nic zatem dziwnego, że w chwili rosnącego zapotrzebowania na bohaterów narodowych autor mitu odwołał się do popularnego i podziwianego herosa, wykorzystując jego imię - Otger Danès - jako matrycę dla skonstruowanej przez siebie postaci - Otgera Cataló. Zwłaszcza, że nasuwające się automatycznie ówczesnemu czytelnikowi skojarzenie z bohatrem będącym symbolicznym nośnikiem etosu rycerskiego przydawało „recyklingowanej” legendzie patosu i odpowiedniej powagi.

Na osobną wzmiankę zasługuje także Dziewięciu Baronów wprowadzonych przez drugą wersję legendy o Otgerze. Podział terytorium Katalonii na hrabstwa, wicehrabstwa oraz wymienienie przydomków rodowych najważniejszych domów szlacheckich świadczą o jej genealogicznym charakterze, który - jak już zostało powiedziane - wynikał z potrzeby politycznej. Wzmocnienie prestiżu dziewięciu towarzyszy Otgera zostało w tym przypad-

10 Trubadur nazywa biskupa odszczepieńcem (renegat), porównuje go do zakłamanego Maura (fals Sarazin) oraz pozwala sobie na wulgarne uwagi dotyczące kompletności biskupich narządów płciowych (q’el non a coillos en la pel), [Riquer, 1971: 87]. Szczera nienawiść Guillema de Berguedà do hierarchy wyrażała się również w innych utworach, jak np. Ben fo ver q’en Berguedan, w którym oskarża biskupa o praktyki homoseksualne [Riquer, 1952]. 
ku zrealizowane przez analogię do postaci tzw. Dziewięciu Bohaterów Świata, znanych także pod nazwą Dziewięciu Książąt lub Dziewięciu Odważnych. Motyw Dziewięciu pojawił się na początku XIV w. we Francji (Les Neuf Preux) i natychmiast zyskał ogromną popularność w całej Europie Zachodniej, jakoże jego bohaterowie reprezentowali rycerski ideał oraz przymioty stanu bellatores. Motyw zorganizowany jest wokół dziewięciu „władców” historycznych i fikcyjnych pogrupowanych w trzy triady. Na pierwszą składają się postaci biblijne, reprezentujące judaizm: Jozue, Dawid i Juda Machabeusz; drugą stanowią bohaterowie pogańscy: Hektor, Aleksander Wielki i Juliusz Cezar; ostatnia natomiast to postaci współczesne, oczywiście w wyobrażeniu człowieka średniowiecza, należące do kręgu kultury chrześcijańskiej: król Artur, Karol Wielki i Gotfryd z Bouillon. Nietrudno zauważyć, że identyczny układ trzech triad zawiera legenda katalońska i chociaż autor odwołuje się do porównania z dziewięcioma chórami anielskimi, baronom niewątpliwie bliżej do Dziewięciu Bohaterów niż archaniołów. Można by się zastanowić, dlaczego zatem legenda nie opiera się na prostszej i dużo bardziej naturalnej analogii? Bezpośrednie wskazanie na Les Neuf Preux miałoby dla reprezentantów stanu rycerskiego, a w owym czasie rycerstwo było domeną wyłącznie szlachecką, o wiele bardziej nobilitujący, bo namacalny charakter. Prawdopodobnym wyjaśnieniem jest rzetelność historyczna autora, nawet jeśli w naszym współczesnym przekonaniu działalność mitotwórcza nie mieści się w kategoriach naukowej rzetelności, ponieważ ten, wprowadzając postać Karola Wielkiego, nie chciał odwoływać się do symbolu, którego francuski władca był częścią.

Kanoniczną formę motywowi Dziewięciu Odważnych nadał słynny, francuski poemat należący do epiki dworskiej, Voeux du paon [Śluby na pawia] Jacques'a de Longuyon, napisany między rokiem 1310 a 1313, ponieważ to w nim Dziewięciu pojawia się po raz pierwszy. Natomiast niezwykła popularność tekstu, który doczekał się aż dwóch kontynuacji: Restor du paon Brisebarre'a (1338) i Parfait du paon Jeana de la Mote' a (1340), przyczyniła się do rozpowszechnienia motywu w Europie. Wersy Voeux du paon poświęcone bohaterom podają skróconą biografię każdego $\mathrm{z}$ nich, pozwalającą na umocowanie chronologiczne i geograficzne postaci, a następnie wymieniają ich najchwalebniejsze sukcesy militarne, budując w ten sposób wzór rycerza-wojownika. Nacisk na aspekt bojowy pojawił się nie bez przyczyny, XIV w. to początek schyłku rycerstwa jako formacji wojskowej, a także moment, w którym wizja literacka staje się narzędziem formowania etosu całego stanu. Stąd też niebagatelna waga motywu Dziewięciu dla kultury rycerskiej, bez wątpienia oczywista dla autora opowieści o Ot- 
gerze, ponieważ już samą aluzją do niego sprawia, że noszący katalońskie przydomki rodowe towarzysze Otgera stają się wzorem do naśladowania dla innych rycerzy i całej arystokracji.

Opowieść o Dziewięciu Odważnych znana była w Katalonii już w XIV w., o czym świadczą takie zabytki, jak: poemat króla Piotra Ceremonialnego Cobles de l'entremès del pagó (Strofy o scenach z pawiem; 1381) stworzony pod wyraźnym wpływem francuskiego Paon; zakupiony w $1351 \mathrm{r}$. przez tego samego władcę arras cum istoria novem militum ( $z$ czynami dziewięciu rycerzy) czy należące do Piotra Portugalskiego arrasy przedstawiające wizerunki dziewięciu rycerzy. Ciekawym śladem niegdysiejszej popularności motywu Les Neuf Preux w Katalonii jest spisany w 1480 roku przez Bernata de Llupià herbarz, Nobiliari, w którym umieszczono godła Dziewięciu Odważnych oraz rodowy herb hrabiów Barcelony przypisany samemu Otgerowi Cataló (o czym szerzej, później), [Coll i Alentorn, 1947-8: 21-2].

Trudno dziś powiedzieć, czy podział Katalonii na dziewięć hrabstw miał w zamyśle autora legendy nieść jakieś dodatkowe znaczenia. Powstał, być może, przez analogię do postaci Dziewięciu Baronów albo, jak sugeruje wybitny XVII-wieczny historyk aragoński, Jerónimo Zurita, jako podział paralelny do dziewięciu hrabstw Akwitanii, zwanej też Novempopulania, regionu, z którego pochodził Otger Cataló [Zurita, 1669: 6b].

\section{Ustalenie najpopularniejszej wersji legendy fundacyjnej i jej dalsze losy}

Niedługo po spisaniu wersji genealogicznej legendy, bo już w 1438 r., powstaje jej kolejny wariant, którego kompilatorem jest Pere Tomic, autor kroniki Històries e conquestes dels reis d’Aragó, zawierającej opis dziejów świata od stworzenia po czasy panowania Alfonsa Wspaniałomyślnego. Kronika Tomica budzi szczególne zainteresowanie historyków, ponieważ zawiera obszerne spisy szlachty katalońsko-aragońskiej, bogatą genealogię rodów szlacheckich oraz legendy związane z historią Katalonii, jak opowieść o Galceranie de Pinós i uratowaniu stu panien albo omawiana tutaj legenda o Otgerze Cataló. Wersja Tomica stanowi połączenie obydwu wcześniejszych, tj. legendy etymologicznej oraz genealogicznej, wprowadza jednak do obydwu pewne zmiany oraz niespójności, wynikające z pewnej niedbałości w korzystaniu z różnych źródeł. Dla przykładu w rozdziale XVI etnonim Katalończycy wywodzony jest z nazwy zamku: 
Trzeba wam wiedzieć, że w roku 733 od wcielenia Jezusa Chrystusa, w prowincji Gujennie znajdował się zamek, który zwany był Cathaló przez wszystkich i zwał się także ów książę Otger Cathaló, ponieważ owa prowincja miała swego księcia, który rządził ową ziemią z nadania Pepina, króla Francji, a ów książę i zarządca nosił imię własne Otger Golant, lecz ponieważ ów książę zamieszkał w zamku Cathaló, przez wszystkich zwani byli [jego ludzie] Cathalons. A ponieważ ów książę był Niemcem i pochodził z wysokiego rodu, i serce pełne miał odwagi i cnót, miał przy sobie dziewięciu Baronów, swoich towarzyszy, a każdy z Baronów pochodził ze znakomitego i szlachetnego rodu; postanowił ów książę z dziewięcioma Baronami, swoimi towarzyszami, podbić ziemię i prowincję zwaną ziemią Gotów, i przeprawić się przez Pireneje, i ową ziemię i prowincję przywrócić wierze chrześcijańskiej [Tomich, 1970: 11].

A dalej, w rodziale XXII, powstałym pod widocznym wpływem kroniki Gesta Karoli Magni ad Carcassonam et Narbonam, Katalończycy zyskują swoje miano na pamiątkę Otgera:

[...] Cesarz [Karol Wielki] ślubował za papieskim przyzwoleniem i po długim namyśle przeprawić się przez Góry Pireneje i przywrócić ową ziemię [Katalonię] wierze Chrześcijańskiej. A owo ślubowanie złożył ów Cesarz ku czci i z szacunku dla Jezusa Chrystusa i pani naszej matki jego, i ku czci IX chórów świętych Aniołów, [...] a ponieważ dobry Książę wyżej wspomniany zwał się Otger Cathaló, który jako pierwszy ze swymi towarzyszami wszedł na ową ziemię po tym, jak zaraza Hrabiego Juliana ${ }^{11}$ ją zajęła, postanowił, że będzie się zwać Principat [Pryncypat], a ponieważ książę nosił nazwisko Cathaló,

11 Nawiązanie do legendy o ostatnim wizygockim królu Roderyku (hiszp. Rodrigo), który pohańbił córkę hrabiego Juliana, sprowadzając w konsekwencji zgubę na całe królestwo, ponieważ hrabia Julian w akcie zemsty doprowadził do inwazji afrykańskich Maurów na hiszpańskie państwo Wizygotów. Liczne wersje legendy obecne w hiszpańskiej literaturze od czasów średniowiecza do dziś wskazują na jej germańskie źródło, np.: poemat z gatunku mester de clerecía pt. Poema de Fernán González, powstały w drugiej połowie XIII w. opowiada, jak to hrabia Julian namówił króla Roderyka, by ten nakazał przekuć całą broń na narzędzia rolnicze, a gdy królestwo pozostało bez obrony, otworzył do niego drogę arabskim wojskom. Motyw złego doradcy, działającego z żądzy osobistej zemsty należy do repertuaru germańskiego folkloru i znany jest np. z norweskiego zbioru opowieści Thidrekssaga (XIII w.), gdzie pojawia się postać króla Ermanaryka (IV w.), który pragnąc zdobyć Odylię, żonę swego doradcy Sifki, wysyła go z niebezpieczną misją, a pod jego nieobecność gwałci Odylię. Sifka, po powrocie, mszcząc się za zniewagę, doprowadza swojego pana i jego ród do zguby [Krappe, 1923]. O możliwych wpływach zbioru Thidrekssaga na hiszpański epos cf. [Montgomery, 2010]. Podobnie jak w przypadku legendy o Otgerze, również historia króla Roderyka ma na celu nobilitację arystokracji sprawującej władzę, wskazując na jej pochodzenie w prostej linii od królów wizygockich. 
ziemię nazwał Cathalunya [Katalonią], a wszyscy jej mieszkańcy, takoż Pryncypatu, zwać się będą Cathalans [Katalończykami], [Tomich, 1970: 16-7].

Tomic uzupełnia skompilowaną przez siebie relację o nowe szczegóły, np. dodaje, że Otgerowi w wyprawie na Katalonię towarzyszył oddział liczący 25 tys. zbrojnych, podaje szczegółową trasę przemarszu wojsk od przełęczy w Vall d’Aran po Empúries, gdzie, jak pamiętamy, umiera Otger, według Tomica w kalendy październikowe 735 r. Wykorzystując symbolikę dziewiątki, historyk informuje o utworzeniu, prócz hrabstw i wicehrabstwa, ośmiu biskupstw i jednego arcybiskupstwa, a także podaje ich nazwy. Zaznacza przy tym, że podziału dokonał Ludwik Pobożny na życzenie rycerzy z drużyny Otgera i zgodnie z wolą swojego ojca, Karola Wielkiego. Podaje imiona Dziewięciu Baronów oraz, odzwierciedlając faktyczną sytuację polityczną swoich czasów, ustanawia hierarchię katalońskich hrabstw, z których dominująca rola przypada Barcelonie. Wersja Tomica, chociaż dość wiernie powtarza treść istniejących już legend, zyskała ogromną popularność, do tego stopnia, że nawet dzisiaj uważana jest przez amatorów historii za pierwszą i oryginalną wersję legendy o Otgerze Cataló. Być może wynika to ze stosunkowo łatwej dostępności tekstu lub z atrakcyjności opowieści, łączącej elementy funkcjonujące do tej pory osobno. Niewątpliwą zasługą Tomica jest utrwalenie wiary w autentyczność Otgera - Ojca Założyciela konfederacji hrabstw zwanej Katalonią, która mogła aspirować do supremacji nad innymi regionami.

W 1448 r. Jaume Marquilles przedstawia Radzie miasta Barcelony zbiór komentarzy do obowiązujących powszechnie praw - Usatges - pod tytułem Commentaria super Usaticis Barchinone. Znajdziemy w nich kolejną wersję legendy o Otgerze, lecz co ciekawe nie jest ona powiązana $\mathrm{z}$ historią skompilowaną przez Tomica, chociaż zawiera wiele podobnych motywów. Pojawiająca się u obydwu autorów hierarchizacja hrabstw wiąże się z wprowadzeniem nowego bohatera, a mianowicie Wilfreda d'Arrià, mianowanego przez Ludwika Pobożnego zarządcą Barcelony, jedynego hrabstwa pozostającego własnością francuskiego króla. Postać Wilfreda d’Arrià wpisuje Otgeriańską legendę w cykl opowieści o wspomnianym wyżej hrabim Wilfredzie Kudłatym, który msząc skrytobójczy mord dokonany na swym ojcu, odbija hrabstwo Barcelony z rąk uzurpatora Salomona, a pod koniec walecznego życia otrzymuje od króla Francji herb w uznaniu zasług na polu bitwy. Łączenie się i zazębianie opowieści fundacyjnych ma bardzo konkretny cel, ponieważ przesuwa w czasie ku przeszłości moment „narodzin” danej wspólnoty, 
uzasadniając jej szeroko pojęte prawa do istnienia przez niepodważalne „tak było od zawsze", będące fundamentem kształtującej się tożsamości.

W tym miejscu warto zwrócić uwagę na dobór imion, jakimi obydwaj autorzy, Tomic i Marquilles, obdarzyli Dziewięciu Baronów. Większość $\mathrm{z}$ nich to imiona charakterystyczne dla danego rodu, jak np. Galceran dla rodziny Pinós, Hugo - dla Mataplana, czy Guillem dla rodu Cervera. Dodatkowo, w przypadku potężnego domu Montacada, jego mityczny założyciel otrzymuje, prócz dowództwa po zmarłym Otgerze, imię Naphiferus, które jest niczym innym, jak błędną grafią tytułu dapifer, czyli seneszal, należącego tradycyjnie do rodziny Montcada [Coll i Alentorn, 1947-8: 25].

W XV w. legenda o Otgerze pojawia się w jeszcze jednym dziele, w ukończonej w 1476 r. kronice Gabriela Turella zatytułowanej Recort. Turell kopiuje niemal dosłownie wersję Tomica, lecz dodaje przy tym ciekawe komentarze odautorskie na temat początków katalońskiej autonomii. Mianowicie w rozdziale 39, podsumowując pozdział Katalonii na dziewięć części i powołowanie dziewięciu hrabstw, wicehrabstw, pisze:

Rozdał każdemu z nich ziemie i miasta rozdzielone na hrabstwa, z owymi przywilejami oraz swobodami, o których wcześniej wspomniałem, a uczynił tak Karol Wielki, bowiem uważał, że majątek jego jest już dość duży i potężny, i że nie powinienen zostawać w Katalonii, ani się w niej osiedlać. I w ten sposób rozdzielił ów pryncypat pomiędzy sobie podległych, bacząc, skąd pochodzili i jacy byli owi, których obdarowywał, i zwolnił ich chętnie [z zależności wasalnej], bowiem widział, że są godni takiego władztwa. I oto jest początek swobód Katalonii, bowiem początek jej był nie w ludziach prostych i przypadkowych, a szlachetnych i odważnych [Turell, 1894: 53].

Wypowiedź Turella pełną dumy narodowej można odczytać jako reakcję na zakończenie wojny domowej z lat 1462-72, kiedy to Katalonia zbuntowała się przeciwko władzy Jana II Aragońskiego, zwanego Janem bez Wiary, syna pierwszego kastylijskiego króla na aragońskim tronie. Nie jest to miejsce na anlizę wewnętrznego konfliktu o kontrolę polityczną nad Pryncypatem Katalonii, warto jednak zwrócić uwagę, że po raz kolejny przypomnienie legendy fundacyjnej Otgera miało na celu uwypuklenie katalońskiej niezależności opierającej się na prawach i swobodach o wielowiekowej tradycji, nawet jeśli była to tradycja mityczna.

W 1495 r. Pere Miquel Carbonell, historyk i archiwista Królewskiego Archiwum w Barcelonie, rozpoczął pracę nad dziełem swojego życia - Chròniques de Espanya - kroniką, która obejmowała okres od czasów 
najdawniejszych po śmierć Jana II. Dla Otgeriańskiej legendy kronika Carbonella ma szczególne znaczenie, ponieważ jest pierwszym dziełem poddającym w wątpliwość autentyczność opowieści o francuskim (lub niemieckim wg niektórych wersji) bohaterze. Co ciekawe, Carbonell wydaje się nie znać żadnej z wersji legendy sprzed 1438 r., ponieważ za jej autora uważa Pere Tomica, błąd, jak się w przyszłości okaże, brzemienny w skutkach. Barceloński kronikarz, nie znajdując dokumentów potwierdzających historyczność postaci Otgera, umieszcza ją, jakże słusznie, w sferze mitu, stając jednocześnie na czele tych badaczy, początkowo niewielu, którzy dążą do uściślenia narracji historycznej i oczyszczenia jej z legendarno-folklorystycznych wtrętów. Mimo wysiłków Carbonella i zwolenników jego wizji historii, większość autorów, aż do XVII w., nie wątpi w autentyczność Otgeriańskiej legendy, o czym świadczą chociażby próby wykorzystania postaci bohatera $\mathrm{w}$ katalońsko-aragońskim sporze o herb ${ }^{12}$. Cztery czerwone pasy na złotym tle są znakiem heraldycznym, którym posługiwały się, i posługują do dziś, wszystkie ziemie należące niegdyś do Królestwa Aragonii: sama Aragonia, ale też Katalonia, Walencja, Baleary czy Sycylia. W czasach, kiedy sfragistyka jeszcze się nie rozwinęła, a heraldyka ograniczała się do tworzenia tzw. roli herbowych, ustalenie, kto pierwszy zaczął się posługiwać czerwono-złotym znakiem było niemożliwe. Jednocześnie zarówno Aragończycy, jak i Katalończycy rościli sobie prawo własności do herbu, którego potwierdzeniem miało być, w przypadku Katalonii, przypisanie go Otgerowi. I tak, w herbarzu wspominanego już Bernata de Llupià znajdziemy zwięzły, acz z punktu widzenia heraldyki jednoznaczny opis: Otger Cathaló: porta or quatre pals de gules (Otger Cataló: w polu złotym cztery czerwone pola $w$ stup), podobnie Luici Marineo Sícul, autor kroniki De primis Aragoniae regibus (Saragossa, 1509), w przekładzie kastylijskim Crónica de Aragón (Walencja, 1524), twierdzi, że znakiem rodowym Otgera były: quatro bastones colorados en campo dorado (cztery czerwone słupy $w$ złotym polu), co oczywiście nie mogło być prawdą, ponieważ pierwsze znaki herbowe pojawiły się dopiero w połowie XII w. W czasach obecnych, kiedy aspiracje niepodległościowe Katalonii zaczynają przekuwać się konkretne działania polityczne, konflikt wokół herbu powrócił, nawet pomimo rozwiązania spornej kwestii przez historyków. Zgodnie z wynikami współczesnych badań heraldycznych, które przytaczam za Riquerem, go-

12 Szczegółowe opracowanie na temat herbu Katalonii oraz legend z nim związanych podaje Martí de Riquer w swojej pracy poświęconej katalońskim legendom historycznym [Riquer, 2000: 13-48]. 
dło będące przedmiotem kontrowersji miało do XIII w. charakter rodowy, nie terytorialny i należało do hrabiów Barcelony. Wraz z przejęciem przez nich korony aragońskiej, stało się z czasem również znakiem królewskim, stąd też jego obecność w herbach Królestwa oraz podległych jej terytoriów. Jednakże wiedza ta autorom takim, jak Llupià czy Sícul nie była dostępna, odwoływali się oni zatem do narodowych emocji i posługiwali bardzo wygodnym argumentem - legendą historyczną [Riquer, 2000: 13-9].

W XVI w. Otger i Dziewięciu Baronów pojawia się obowiązkowo we wszystkich pracach na temat historii Katalonii, przy czym wszystkie wersje legendy bazują na pracy Tomica i wprowadzają jedynie drobne zmiany do utrwalonej już i rozpowszechnionej opowieści. Dopiero w następnym stuleciu legenda zyskuje jedno, za to bardzo istotne rozszerzenie: Gaspar Escolano w kronice Década primera de la Historia de la insigne y coronada Ciudad y Reyno de Valencia wydanej w 1610 roku, po raz pierwszy w historii ewolucji Otgeriańskiej opowieści, nazywa Dziewięciu Baronów Sławnymi (Nou Barons de la Fama). Przydomek ten wpisał się w patriotyczną interpretację legendy tak silnie, że dziś jest znakiem rozpoznawczym dziewięciu towarzyszy Ojca katalońskiej Ojczyzny i symbolem prawości i szlachetności „pierwszych Katalończyków”.

Prace Escolana oraz Jeroniego Pujadesa, autora Crònica universal del principat de Cathalunya (1614), i Estabana de Corbera (Cataluña ilustrada, 1624) należały do ostatnich, kończących okres apogeum zainteresowania legendą Otgera. Pujades zbiera i systematyzuje wszystkie wersje opowieści, próbując je uzgodnić i, tym samym, podsumować i zakończyć niemal dwustuletni okres ewolucji mitu. Podobnie Corbera, który sporządza listę wszystkich autorów zajmujących się postacią bohatera oraz cytuje obszerne fragmenty $\mathrm{z}$ ich dzieł. Od tej chwili Otger funkcjonuje na marginesie historii, bardziej jako ciekawostka niż uczestnik faktycznych wydarzeń, ponieważ jego autentyczność nie została ani potwierdzona ani obalona. Od 1716 r., kiedy w Katalonii wprowadzono absolutystyczny reżim Filipa V (tzw. Dekrety Nowego Porządku - Decrets de Nova Planta), region zaczął ulegać stopniowej kastylizacji i dopiero okres Renaixença (katalońskie odrodzenie narodowe) w drugiej połowie XIX w. przywrócił zainteresowanie przeszłością Katalonii, w tym legendarną postacią Otgera.

Za sprawą, jak pisze Coll i Alentorn, „nieokiełznanej fantazji” pisarza i polityka Víctora Balaguera [Coll i Alentorn, 1947-8: 42] czyny Otgera i Dziewięciu Słynnych Baronów powracają na karty historii w nowej odsłonie. W dziele Bellezas de la historia de Cataluña (1853) Balaguer przytacza 
raz jeszcze legendę fundacyjną, z całym bogactwem szczegółów uzupełnionych o nowe, sugestywne elementy: Herkulesową maczugę w rękach bohatera oraz lwią skórę na jego ramionach:

Mówi się, że przywódca chrześcijan był człowiekiem gigantycznej postury, o wyglądzie szlachetnym, acz dzikim, i spojrzeniu pełnym ognia. Nosił zawsze na odzieży wierzchniej skórę z lwa, którego sam w górach ubił, a walczył maczugą, z łatwością jakby machał trzcinka, choć trzech ludzi zwykłej siły było mało, aby ją unieść [Balaguer, 1853: 95].

W podniosłym, patriotycznym zapale Balaguer widzi w Otgerze męża opatrznościowego Katalonii, prawdziwego Ojca Ojczyzny i, o dziwo, historycznego bohatera:

Był mężem, który chciał dla Katalonii być tym, kim w odległej przyszłości był Herkules dla Grecji, w bliżyszch mu czasach Pelayo dla Asturii, i tym, kim w przyszłości miał się stać Roland dla Francji, a później Cyd dla Kastylii. Zwał się Otger Cataló, a to znaczy Herkules, Pelayo, Roland i Cyd Katalonii [Balaguer, 1853: 93].

Chociaż w swojej wierze w autentyczność postaci Otgera Balaguer pozostaje odosobniony, to nie jest jedynym, który przywraca $\mathrm{z}$ martwych bohatera. W 1885 r. wystawiono sztukę teatralną Antoniego Ferrer i Codiny, pod znaczącym tytułem Otger. Jej akcja rozgrywa się w trakcie oblężenia Empúries, jednak główną osią wydarzeń nie są wątki patriotyczne, a romansowe, główny bohater nie jest ani Frankiem ani Niemcem, a synem Gota i Saracenki, i, co warto podkreślić, staje się bohaterem romantycznej popkultury. Natomiast w symbolicznej roli opiekuna katalońskiej wspólnoty Otger pojawia się dziewiątej pieśni poematu Jacinta Verdaguera Canigó, gdzie ratuje pięciu mnichów z klasztoru w Eixalada:
Al monestir
nos acabàvem d'adormir,
quan l'espetec
nos desvetllava a tots en sec.
Del llit saltam
i a mig vestir al cor baixam.
És la capella,
com ull al cloure sa parpella,
niu de foscor. 
Per fer-nos créixer més l'horror,

a la llum vaga

de la humil llàntia que s'apaga,

l'ombra d'Otger

veiem sortir de son carner

signant la porta,

que obre amb un colp de maça forta.

Cinc solament,

cinc la seguim fora el convent

a corre-cuita,

esfereïts prenent la fuita

muntanya amunt.

[W klasztorze posnęliśmy właśnie, gdy hałas głuchy ze snu nas wszystkich wyrwat. Z łóżek wyskoczyliśmy i zbiegliśmy do chóru, jeszcze wpół odziani. Kaplica była niczym gniazdo ciemności, kiedy powieka zakryje oko. Większe jeszcze przerażenie ogarnęło nas, gdyśmy ujrzeli w słabym świetle nędznej, przygasłej latarni, widmo Otgera wychodzace z urny, które wskazawszy na drzwi, otwarło je jednym, silnym ciosem maczugi. Ledwo w pięciu ruszyliśmy za nim, biegnąc w przerażeniu górskim zboczem.]

\section{Podsumowanie}

Dziś nie ma już najmniejszych wątpliwości co do apokryficznego charaktery legendy o Otgerze i Dziewięciu Baronach, jednak po okresie zapomnienia powoli wraca ona do łask, już nie ze względów historycznych, a emocjonalnych. W Katalonii 9 listopada 2014 r. odbyło się w symboliczne referendum, w którym uprawnieni do głosowania Katalończycy mieli odpowiedzieć na dwa pytania: „Czy chcesz, żeby Katalonia stała się państwem?” i jeśli tak, „Czy chcesz, by państwo to było niepodległe?”. Pomimo dwóch orzeczeń Trybunału Konstytucyjnego w Madrycie (pierwsze z 29 września 2014 i drugie z 4 listopada tego samego roku), który, powołując się na zapisy hiszpańskiej konstytucji dotyczące integralności terytorialnej państwa, uznał planowane referendum za niekonstytucyjne i nielegalne oraz zakazał organizowania go również $\mathrm{w}$ formie nieprawomocnej konsultacji społecznej, w głosowaniu wzięło udział 33\% uprawnionych, z których blisko 81\% opowiedziało się za niepodległością regionu. Wynikające z konstytucjonalnego zakazu formalne ograniczenia przełożyły się na niską reprezentatywność wyników referendum w stosunku do całości katalońskiej opi- 
nii publicznej. Dla porównania, w sondażach przeprowadzonych przez Generalitat de Catalunya (Kataloński Rząd Autonomiczny) w marcu i czerwcu 2015 r. poparcie dla idei niepodległościowej wynosiło, odpowiednio, 44,1\% i 42,9\% [„El País”: 03.07.2015]. Jednak wyników listopadowego głosowania nie można tak po prostu zignorować, nawet pomimo wyraźnie tendencyjnej postawy jego uczestników, wskazują one bowiem na bardzo istotną zmianę w świadomości wspólnotowej mieszkańców Katalonii, jaka nastąpiła w ostatnich latach.

Katalończycy, po raz pierwszy tak licznie (swój głos oddało ponad $2 \mathrm{mln}$ obywateli na niemal $7 \mathrm{mln}$ uprawnionych), odmówili podporządkowania się prawu stanowionemu w Madrycie i odwołując się do poczucia sprawiedliwości społecznej oraz wartości uznawanych za ważne i powszechnie szanowane, jak wolność wypowiedzi czy prawo człowieka do decydowania o sobie, postanowili wyrazić swoją opinię na drodze nieposłuszeństwa obywatelskiego, to jest głosując. Zakrojona na tak szeroką skalę kontestacja porządku prawnego - a trzeba pamiętać, że głosowanie wspierane było przez autonomiczny rząd i katalońską policję (Mossos d'Esquadra), co tylko podkreśla rewolucyjność postawy przyjętej przez lokalną administrację publiczną - wynikała z rozbudzonej przez ruch niepodległościowy pamięci historycznej i przekonania o przynależności do odrębnej kulturowo, językowo oraz politycznie wspólnoty o charakterze narodowym. Lata frankistowskiej dyktatury, której przyświecała idea jedności religijnej, społecznej i politycznej, a potem rządy centralne nastawione na utrzymanie tejże jedności, doprowadziły w Katalonii na początku XXI w. do prawdziwego wybuchu emocji o charakterze patriotycznym, w które wpisana została również Otgeriańska legenda.

Obecnie obowiązującą wersję podał znakomity kataloński folklorysta i etnolog Joan Amades [Amades, 1996]. Można ją znaleźć na stronie katalońskiej Wikipediii ${ }^{13}$, wśród trzystu miniopowieści filmowych nagranych przez internetową telewizję VilaWeb z okazji 300 rocznicy oblężenia i upadku Barcelo-

13 Potraktowanie tematów patriotycznych, zarówno tych historycznych, jak i literackich, przez redaktorów katalońskiej Wikipedii zasługuje na szczegółową analizę, ponieważ wpływa na kształtowanie opinii publicznej. Wikipedia jest najczęściej konsultowaną encyklopedią internetową, a dla wielu użytkowników sieci jedynym źródłem informacji encyklopedycznej. Wyraźnie niepodległościowy charakter artykułów na tematy historyczne pisanych w języku katalońskim i opierających się na wyselekcjonowanym, a jednocześnie wartościowym materiale źródłowym (w większości przypadków), musi przekładać się na postrzeganie rzeczywistości przez młode, internetowe pokolenie, a w rezultacie na kształtowanie własnej świadomości narodowej i konkretne decyzje, np. wyborcze. 
ny oraz w dziesiątkach publikacji, zarówno tradycyjnych, papierowych, jak i internetowych, o charakterze historycznym, edukacyjnym, rozrywkowym czy politycznym. Otger nie jest zresztą jedynym bohaterem, do którego odwołują się dzisiaj zwolennicy państwotwórczych aspiracji katalońskich. Wznawia się średniowieczne kroniki, we współczesnych adaptacjach, przypominające o świetności Katalonii w czasach istnienia Korony Aragonii, hucznie obchodzone są rocznice śmierci lub urodzin wielkich postaci, jak Ramon Muntaner, którego 750 rocznicę urodzin obchodzono w 2015 r., czy Ramon Llull, bohater roku 2016, poświęconego wspomnieniu 700 rocznicy śmierci filozofa. Wygrana w przeprowadzonych we wrześniu 2015 r. lokalnych wyborach parlamentarnych niepodległościowego ugrupowania Junts pel Sí pozwala przypuszczać, że dojdzie do przełożenia nastrojów społecznych na konkretne działania polityczne. Postać Otgera nie jest oczywiście najistotniejszą spośród uznanych bohaterów katalońskiej historii, jednak jej trwała obecność we wspólnotowej świadomości ukazuje, jak głęboko zakorzeniona jest wśród Katalończyków idea narodowa oraz przekonanie o słuszności państwotwórczych aspiracji.

\section{Bibliografia}

Aguiló i Fuster, Marian (1934), Diccionari Aguiló, Barcelona, Institut d’Estudis Catalans. Amades, J. (1996). Les Millors llegendes populars, Barcelona, Selecta.

Balaguer, V. (1853). Bellezas de la historia de Cataluña, Barcelona, Imprenta de Narciso Ramírez.

Balcells, A. (2004). Història de la historiografia catalana, Barcelona, Institut d'Estudis Catalans.

Barceló Perello, M. (1979). Una nota entorn del «Llibre dels reis francs» regalat pel bisbe Gotmar de Girona, l'any 380-940, a Al-halkam, a Còrdova, „Annals de l'Institut d'Estudis Gironins", nr 25(1): 127-136.

Barrau-Dihigo, L., \& Massó Torrents, J. (2007). Gesta comitum barcinonensium : textos llatí i català (Edició facsímil), Barcelona, Institut d'Estudis Catalans.

Caja López, F. (2011). La raza catalana: El núcleo doctrinal del catalanismo, Madryt, Encuentro.

Cingolani, S. M. (2011). Gestes dels Comtes de Barcelona i Reis d'Aragó, Walencja, Universitat de València.

Coll i Alentorn, M. (1947-8). La Llegenda d'Otger Cataló i els nous barons, „Estudis Romànics", 7-50.

d'Opinió, C. d. (2015). Baròmetre d'Opinió Política. Dossiers de premsa, Barcelona, CEO, Generalitat de Catalunya. 
Flórez de Setién, E., \& Risco, M. (1819). España sagrada. Theatro geographico-historico de la iglesia de España. Origen, divisiones, y terminos de todas sus provincias. Antiguedad, traslaciones, y estado antiguo y presente de sus sillas, en todos los dominios de España, y Portugal... (t. XIII), Madryt, Pedro Marin.

Krappe, A. H. (1923). The legend of Roderick: last of the Visigoth kings, and the Ermanarich cycle, Heidelberg, Winter.

Martínez Llorente, F. (2014). Cataluña en sus orígenes. La Marca Hispánica, una frontera entre dos mundos. En I. Ruiz Rodríguez, Cataluña en España. España en Cataluña. Trece visiones académicas sobre una verdad única (págs. 17-34), Madryt, Editorial Dykinson.

Montgomery, T. (2010). Medieval Spanish Epic: Mythic Roots and Ritual Language, Penn State Press.

Philomena. (1898). Gesta Karoli Magni ad Carcassonam et Narbonam, F. E. Schneegans, (red.), Halle S. M. Niemeyer.

PmC. (2006). Poema de mio Cid, R. Menéndez Pidal, (red.), Madryt, Austral.

Riquer, M. (1952). Las poesías de Guilhem de Berguedán contra el obispo de Urgel, „Studi medievali", nr (18): 272-291.

Riquer, M. (1971). Guillem de Berguedà, t. 2, Poblet, Abadía de Poblet.

Riquer, M. (1980). Història de la literatura catalana, t. 1, Barcelona, Ariel.

Riquer, M. (2000). Llegendes històriques catalanes, Barcelona, Quaderns Crema.

Sholod, B. (1966). Charlemagne in Spain: The Cultural Legacy of Roncesvalles, Librairie Droz.

Soldevila, F. (1962). Història de Catalunya, t. 1, Barcelona, Editorial Alpha.

Sunyer, M. (2014). Mites per a una nació. De Guifré el Pelós a l'Onze de Setembre, Vic, Eumo Editorial.

Tomich, P. (1970). Històries e conquestes dels reis d'Aragó e comtes de Catalunya (faksymil wydania z 1534 ed.), Walencja, Anubar.

Turell, G. (1894). Recor, Barcelona, Imprempta i Llibreria de L'Avenç.

Valls i Taberner, F., \& Soldevila, F. (2002). Història de Catalunya, Barcelona, L’Abadia de Montserrat.

Zurita, J. (1669). Anales de la corona de Aragón, t. 1, Saragossa.

\section{Inne źródła}

Baròmetre d'Opinió Política (2015), Barcelona, Centre d'Estudis d'Opinió i Generalitat de Catalunya. 


\section{STRZESZCZENIE}

W artykule omawiano kwestię kształtowania się katalońskiej tożsamości narodowej od IX do XV w., koncentrując się na fundacyjnej legendzie Otgera Cataló - fikcyjnej postaci „Ojca ojczyzny” (Pare de la Pàtria). Początkowo katalońska wspólnota określała się przez samoporzpisanie do wspólnoty politycznej Franków (IX - XII w.), a endoetnonim Katalończycy podkreślający jej odrębności względem sąsiadów pojawił się dopiero w XII w. Fundacyjna legenda Otgera pojawiła się w XV stuleciu kontekście politycznym, jako odpowiedź katalońskiej szlachty na próby odsunięcia jej od władzy przez pierwszego władcę z kastylijskiej dynastii Trastamara zasiadającego na aragońskim tronie. Pierwsza wersja legendy, spisana w 1418 r., ma charakter etymologiczny i umieszczając mityczne początki Katalonii w 732 r., legitymizuje przez dawność nacji jej prawo do samostanowienia. Kolejna wersja, powstała w 1431r., ma charakter genealogiczny i podkreśla, podobnie jak późniejsze warianty, znaczenie katalońskiej arystokracji. W XIX w., w okresie katalońskiego odrodzenia narodowego, legenda Otgera Cataló była wykorzystywana do rozbudzenia świadomości narodowej. Podobnie dziś, stanowiąc jeden $\mathrm{z}$ wielu elementów narodowej mitologii, służy umacnianiu katalońskiej odrębności, a w konsekwencji państwotwórczych aspiracji.

\section{Słowa kluczowe:}

Katalonia, katalońska tożsamość narodowa, Otger Cataló, katalońskie legendy fundacyjne.

\section{SUMMARY}

The article describes formation of the Catalan national identity in the period from the $9^{\text {th }}$ to the $15^{\text {th }}$ century, focusing on the foundational legend of Otger Cataló a fictional character called "Father of the Nation" (Pare de la Pàtria). Initially, the Catalan community defined itself by self-assignation to the Franks' political community $\left(9^{\text {th }}-12^{\text {th }}\right.$ century), And the endonym Catalans, emphasizing its distinctiveness in relation to the neighbours, came only in the $12^{\text {th }}$ century. The foundational legend of Otger appeared in the $15^{\text {th }}$ century in a political context, as a response of the Catalan nobility to an attempt to offset it from power, which was made by the first ruler of the Castilian dynasty of Trastámara on the throne of Aragon. The first version of the legend, written in 1418, has etymological character and places the mythical origins of Catalonia in the year 732. Another version, founded in 1431, is a genealogical one and highlights, likewise its later variants, the importance of the Catalan aristocracy. In the $19^{\text {th }}$ century, during the Catalan 
national revival, the Otger Cataló legend was used for the awakening of national consciousness. Similarly today, being one of the many elements of national mythology, strengthens the idea of the Catalan autonomy and, in consequence, of the state-building aspirations.

\section{Keywords:}

Catalonia, Catalan national identity, Otger Cataló, Catalan foundational legends. 